\title{
Textiles in Tissue Engineering -A Review of Some Significant Trends
}

\author{
Gokarneshan N* \\ Department of Textile Technology, Park College of engineering and technology, India
}

Submission: May 10, 2018; Published: July 16, 2018

*Corresponding author: Gokarneshan N, Department of Textile Technology, Park College of engineering and technology, Coimbatore, India, Email: advaitcbe@rediffmail.com

\begin{abstract}
The article provides useful insights on some recent and significant trends in the role of textiles in tissue engineering. Textile scaffolds can be found in a variety of application areas in regenerative medicine and tissue engineering. In the present study we used electrostatic flocking-a well-known textile technology-to produce scaffolds for tissue engineering of bone. Flock scaffolds stand out due to their unique structure: parallel arranged fibers that are aligned perpendicularly to a substrate, resulting in mechanically stable structures with a high porosity. The benefits offered by microfibrous scaffold architectures fabricated by textile manufacturing techniques are discussed. The problems related to the development of biomaterial fibers (especially from nature-derived materials) ready for textile manufacturing are addressed.
\end{abstract}

Keywords: Tissue engineering; Textile scaffolds;Microfibrous architectures; Regenerative medicine; Flock technology

\section{Introduction}

The use of fibers as material for sutures in surgery is a very long-standing and also simple application of textiles in medicine. By the use of certain textile technologies it is also possible to generate complex structures and three dimensional designs.

The reason why textiles are used in regenerative medicine and tissue engineering is that they exhibit many advantages over other methods to fabricate scaffolds. One is the excellent surface-to-volume ratio of fibers and therefore also of the resulting textile structures. With their large surface, fibersoffer a huge area for cell adhesion and are therefore effective for the cultivation of cells. By varying the fiber diameter or distance, as well as surface properties of the fibers, the characteristics of scaffolds can be changed very easily. Different textile technologies like electrospinning, weaving, knitting, etc. allow for the variation of the properties and the adaptation to the particular application [1-4]. Ramakrishna has reviewed the variety of textile technologies which may be utilized for scaffold production [5].

The classical Tissue Engineering (TE) approach (in vitro expansion of cells seeded on scaffolds and subsequent implantation) has been facing various critical obstacles concerning the translation to the bedside, namely seedingtime, laborious effort and cost [6-8]. Hence, in recent years in situ TE has gained increasing attention [9-13]. In this more straight-forward approach, the body's own biologic resources and reparative capability are utilized by implanting a cell-free engineered biomaterial (scaffold) into the site of injury, where host stem cells or tissue specific progenitor cells are recruited.

\section{Technology for new textile scaffolds in tissue engineering}

Flock Technology: Flock technology is a well-known and often applied textile technology. Originally developed for the improvement of visual appearance and haptics, flocking can nowadays also be found in technical applications.

Electrostatic flocking means to apply short fibers on a substrate that is covered with adhesive in an electrical field so that the fibers are nearly vertical to the substrate[14]. In the electrostatic field the fibers are aligned and accelerated towards the adhesive coated substrate(Figure 1). Reaching the adhesive layer the fibers become stuck perpendicularly to the substrate and give the surface a velvet-like look.

Flock technology has been used for the fabrication of a new type of scaffold for tissue engineering. The purpose of a tissueengineered scaffold is to mimic the properties of the Extracellular Matrix (ECM) of the tissue that should be restored as well as possible and temporarily adopt its function. For that to happen a scaffold has to be mechanically stable, serve as matrix for cell 
adhesion, proliferation and differentiation, allow nutrient and oxygen support and provide enough space for newly synthesized matrix and blood capillary ingrowth. Most tissues in the body exhibit anisotropic properties so that anisotropic replacement materials are better suited than isotropic ones.

In previous experiments flock technology has been adapted from the textile industry for the fabrication of scaffolds for tissue engineering by successfully replacing the adhesive and the substrate with biocompatible and degradable materials [15]. It could also be shown that the scaffolds were stable under cell culture conditions.

It has been aimed to create scaffolds with different properties by varying both flocking fiber geometry and flocking time. The generated scaffolds were characterized with regard to their biomechanical properties. In cell culture experiments they were loaded with human mesenchymal stem cells to investigate the ability of cells to differentiate into osteoblasts in flock scaffolds.

Scaffolds for tissue engineering applications that were produced by electrostatic flocking which is a well-known textile technology has been considered. These flock scaffolds possess anisotropic properties. They show compression strength along the fibers and are flexible (depending on the substrate used) across the fibers which allows for good handling and adaption to tissue defects. This novel type of scaffold therefore combines favorable qualities which make it applicable for different tissues in the body. Because of the high compression strength in fiber direction, it appears that flock scaffolds are advantageous for load-bearing tissues like bone and cartilage.

It has been demonstrated that scaffolds produced by flock technology offer an oriented and open pore structure with a high surface-to-volume ratio that allows for easy seeding and migration of cells into the constructs. Flock scaffolds supported attachment and proliferation of hMSCs as well as differentiation along the osteoblastic lineage.

For an application in cartilage tissue engineering, in particular, non-mineralized substrates would be more suitable than the mineralized ones we used for the present study. First experiments with a non-mineralized collagen-membrane made from bovine pericardium-Lyoplant ${ }^{\circledR}$ (B. Braun, Melsungen, Germany)-as substrate, were very promising and led to stable scaffolds. The encouraging results from the present, and also from a previous, study concerning the utilization of flock scaffolds for cartilage replacement $[16,17]$ suggest that this new type of matrix might be suitable for the engineering of different tissues-merely needing to adapt materials used for scaffold fabrication to the respective tissue.

Further improvement of the scaffolds must be carried out to make them fully degradable. Promising results from preliminary experiments using fibers made of chitosan encourage our belief that this goal may well be achieved in the near future.

\section{Cell free textile scaffolds in tissue engineering applications}

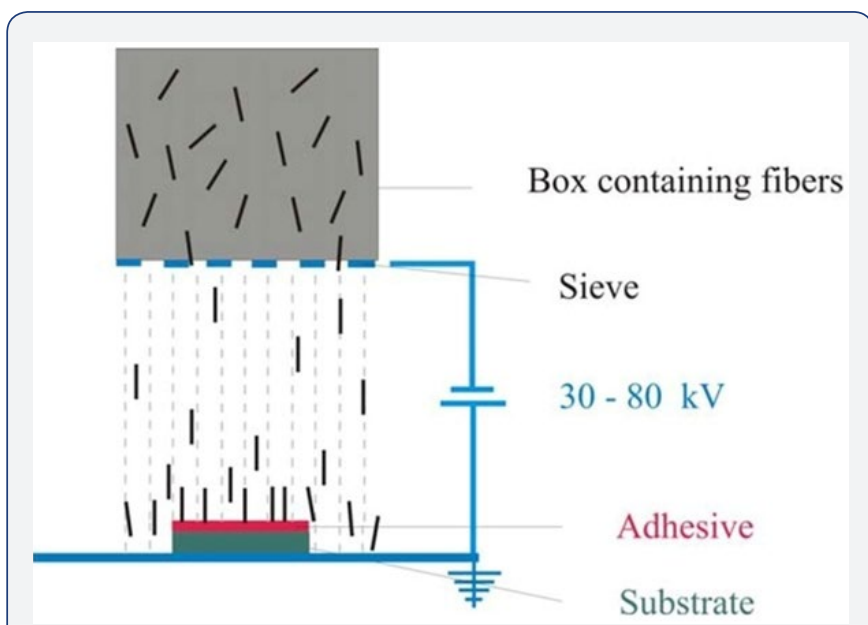

Figure 1: Schematic representation of the flocking process.

In situ TE approaches have been investigated for various possible applications such as vascular grafts, nerve and hard tissue regeneration [18-20]. In recent years the general understanding of the requirements imposed on scaffolds for TE applications has changed towards templates which replicate the target cell niche in terms of their structural architecture and which are capable of adapting to a changing microenvironment, thus providing optimal conditions for tissue-ingrowth, nutrient, gas and biomolecule transport and vascularization [21,22]. The scaffoldarchitectureshouldbedictatedbytherequirementsof the target cell niche (Figure 1). To generate scaffolds with properties tailored to the targeted application, numerous manufacturingmethodshavebeenemployed.Thosecomprise solvent casting [14-16], gas foaming [17-19], phase separation [20,21], emulsion freeze drying [23-33];[14-24], Additive Manufacturing(AM)techniques[25-27],electrospinning[28,29] and otherfiber formation techniques [30,31]. The versatility of textile technology allows for the fabrication of 3D spatial structures with tunable properties in the micro- and macro range $[32,33]$. In the past decades, textile manufacturing techniques have been used in a wide range of engineering applications such as fiber reinforced composites, construction textiles, filtration, medical textiles etc. [34-36]. Fiber based techniques including electrospinning have been successfully used for the manufacturing of 3D cell laden scaffolds for classical in vitro and in vivo TE approaches, whicharereviewedelse-where[37,38]. Through suitable combinations of material, fiber type and manufacturing technique, fiber-based scaffolds can be engineered to obtainpropertiessimilartonativetissueandtomatchcritical scaffold criteria [39]. The mechanical properties can be adjusted according to the desired properties of native tissue [40-42].Besides, closestructuralresemblanceofthescaffold to native host tissue, the success of in situ TE approaches stronglyreliesonthescaffolds capabilitytorecruithoststem cells 
or tissue specific progenitor cells. Therefore, informationrich scaffolding systems with incorporated "cell homing" or "recruiting" factors are needed [43]. Nanofiber based scaffolds have been reviewed in detail elsewhere $[44,45]$. Hence, in this review nanofibers are considered in terms of a major technique for scaffold functionalization and not as structure defining component. In this article, the benefits offered by micro-fibrous scaffold architectures fabricated by textile manufacturing techniques are discussed:

a. How can established and novel fiber-processing techniques be exploited in order to generate templates matching the demands of the target cell niche?

b. Which are the problems related to the development of biomaterial fibers ready for textile manufacturing? How may biological cues be incorporated into microfibrous scaffold architectures?

c. After a critical review of exemplarily selected recent studies on cell-free fiber based scaffolds for in situ TE, including clinical trials, the findings of this article are concluded in order assess the potential and limitations of cell-free fiber based scaffolds.

In this review, the preconditions and possibilities of textile manufacturing methods, fiber development and functionalization for the fabrication of cell-free scaffolds for in situ TE have been summarized. Studies in this field encompass a variety of engineered scaffolds from simple grafts to complex multi-material scaffolds $[46,47]$. The basic benefits of fibrous scaffold architectures, namely mechanical stability, porosity and degradability, are employed in most cases. However, fibrous engineered scaffold systems stay behind the possibilities which are principally offered by textile manufacturing techniques and their combination with other manufacturing techniques. In order to make use of the whole range of favors, there are four main issues which need to be addressed:

i. Logical combination of manufacturing techniques and materials.

ii. Biomaterial fiber development.

iii. Adaptionoftextilemanufacturingtechniquestothedemands of scaffolds for regenerative medicine.

iv. Incorporation of biological cues (e.g. stem cell homing factors).

A crucial premise for successful scaffold development is that the choice of material, manufacturing techniques and biological cues must be dictated by the targeted repair-tissue. The paradox of expert knowledge in specific techniques on the one hand and a broad overview about the huge variety of existing materials and techniques on the other hand may only be solved if intense interdisciplinary collaboration is consequently pursued. The combination of appropriate materials, manufacturing and functionalization techniques must be derived from the desired scaffold-properties [48].

Besides the well-established synthetic polymers (e.g. PLA, PGA, PLGA, PBT), recent developments in biomaterial fiber engineering enable the exploitation of the favorable material properties from materials such as collagen, chitosan, regenerated silk or recombinant proteins in fibers suitable for their processing into stable spatial scaffolds [49-52]. However, intensified studies concerning fiber properties and the in vitro and in vivo behavior of those newly developed fibers have to be conducted in order to use them for regenerative medicine. Furthermore, regulatory restrictions regarding the use of novel fibrous materials in the human body must be taken into account[53].

The possibilities offered by textile manufacturing techniques to create structures with adjusted mechanical and porous properties may only be exploited if the manufacturing method is chosen based on the demands of the targeted tissue. Manufacturing methods have to be adapted in orderto allow the combination of the fibrous architecture with other materials (e.g. nano-fibers, hydrogels), thus creating structurally hierarchical "hybrid" scaffolds which match the host tissue. Also, techniques by which 3D net shaped geometries (similar to AM techniques) may be fabricated from fibers are to be further developed [54], thus allowing simple fabrication of custom-shaped and patient specific fibrous scaffolds.

EspeciallyforinsituTE,theincorporationandsustained release of biological cues into scaffolds is crucial for their successful application. Despite this fact, the incorporation of biological cues is not looked at in most cases when fiber-based cell-free scaffolds are used for in situ TE. A functioning fiber-based release-system for the sustained delivery of biological cues could help in achievinganimportantgoalinguidinghostcellstoform a well-integrated functional structure. Therefore, intensified research is necessary.

Depending on the type of engineered tissue and the application, clinical studies showed that cell-free fibrous scaffolds may be superior to or as well as conventional "gold standard" treatments [55-57]. Besides the obvious advantages of in situ TE (off-the-shelve scaffold availability, less cost and time consumption) it has to be considered that in terms of tissue ingrowth, tissue formation and regained functionality of regenerated tissue, cellfree fibrous scaffold systems do not always yield better results as their cell-seeded counterparts [58]. With the availability of novel biomaterial fibers with sufficient mechanical performance for textile manufacturing techniques and the appropriate addition and sustained release of cell homing factors and growth factors, in situ TE approaches using cell-free fibrous scaffolds could be elevated to various clinical applications.To make progress towards this goal, the interdisciplinary collaboration of experts in the fields of 


\section{Current Trends in Fashion Technology \& Textile Engineering}

medicine, biomaterials science and textile engineering has to be consequently pursued.

\section{Conclusion}

Textile scaffolds can be found in a variety of application areas in regenerative medicine and tissue engineering. Electrostatic flocking-a well-known textile technology-to produce scaffolds for tissue engineering of bone, has been used. Flock scaffolds stand out due to their unique structure: parallel arranged fibers that are aligned perpendicularly to a substrate, resulting in mechanically stable structures with a high porosity. In compression tests we demonstrated good mechanical properties of such scaffolds and in cell culture experiments we showed that flock scaffolds allow attachment and proliferation of human mesenchymal stem cells and support their osteogenic differentiation. These matrices represent promising scaffolds for tissue engineering.

The problems related to the development of biomaterial fibers (especially from nature-derived materials) ready for textile manufacturing are addressed. Attention is also paid on how biological cues may be incorporated into micro-fibrous scaffold architectures by hybrid manufacturing approaches (e.g. nanofiber or hydrogel functionalization). After a critical review of exemplary recent research works on cell-free fiber based scaffolds for in situ TE, including clinical studies, we conclude that in order to make use of the whole range of favors which may be provided by engineered fibrous scaffold systems, there are four main issues which need to be addressed:

1. Logical combination of manufacturing techniques and materials.

\section{Biomaterial fiber development.}

3. Adaption of textile manufacturing techniques to the demands of scaffolds for regenerative medicine.

4. Incorporation of biological cues (e.g. stem cell homing factors).

\section{References}

1. Holzwarth JM, Ma PX (2011) Biomimetic nanofibrous scaffolds for bone tissue engineering. Biomaterials 32(36): 9622-9629.

2. McCullen SD, Ramaswamy S, Clarke LI, Gorga RE (2009) Nanofibrous composites for tissue engineering applications. Wiley Interdiscip Rev Nanomed Nanobiotechnol 1(4): 369-390.

3. Sell SA, Wolfe PS, Garg K, McCool JM, Rodriguez IA, et al. (2010) The use of natural polymers in tissue engineering: A focus on electrospun extracellular matrix analogues. Polymers 2(4): 522-553.

4. Houis S, Deichmann T, Veit D, Gries T (2009) Medizinischetextilien In: Medizintechnik: Life Science Engineering, 5th edn.; Wintermantel E, Ha SW, Eds.; Springer: Berlin, Germany, pp. 961-992.

5. Ramakrishna S (2001) Textile scaffolds for tissue engineering. In Tao X (Ed.), Smart Fibers, Fabrics and Clothing. CRC Press: Boca Raton, FL, USA pp. 291-313.

6. Woodruff MA, Lange C, Reichert J, Berner A, Chen F, et al. (2012) Bone tissue engineering: from bench to bedside. Mater Today 15(10): 430-435.
7. Ko IK, Lee SJ, Atala A, Yoo JJ (2013) In situ tissue regeneration through host stem cell recruitment. Exp Mol Med 45: e57.

8. Hollister SJ (2009) Scaffold design and manufacturing: from concept to clinic. Adv Mater 21(32-33): 3330-3342.

9. Fioretta ES, Fledderus JO, Burakowska-Meise EA, Baaijens FPT, Verhaar MC, et al. (2012) Polymer-based scaffold designs for in situ vascular tissue engineering: controlling recruitment and differentiation behavior of endothelial colony forming cells. Macromol Biosci 12(5): 577-590.

10. Jakob F, Ebert R, Rudert M, Noeth U, Walles H, et al. (2012) In situ guided tissue regeneration in musculoskeletal diseases and aging Implementing pathology into tailored tissue engineering strategies. Cell Tissue Res 347(3): 725-735.

11. Janicki P, Richter W (2012) New approaches for in situ regeneration and tissue engineering of bone. Dtsch Z Sportmed 63(2): 30-35.

12. Chen F, Wu L, Zhang M, Zhang R, Sun H (2011) Homing of endogenous stem/progenitor cells for in situ tissue regeneration: promises, strategies, and translational perspectives. Biomaterials 32(12): 31893209 .

13. Sengupta D, Waldman SD, Li S (2014) From in vitro to in situ tissue engineering. Ann Biomed Eng 42(7): 1537-1545.

14.Bersev JN, Liebscher U (1983) Elektrostatisches Beflocken; Fachbuchverlag: Leipzig, Germany.

15. Walther A, Bernhardt A, Pompe W, Gelinsky M, Mrozik B, et al (2007) Development of novel scaffolds for tissue engineering by flock technology. Textile Res J 77(11): 892-899.

16. Steck E, Bertram H, Walther A, Brohm K, Mrozik B, et al. (2010) Enhanced biochemical and biomechanical properties of scaffolds generated by flock technology for cartilage tissue engineering. Tissue Eng A 16(12): 3697-3707.

17. Walther A, Hoyer B, Springer A, Mrozik B, Hanke T, et al. (2012) Novel Textile Scaffolds Generated by Flock Technology for Tissue Engineering of Bone and Cartilage. Materials 5(3): 540-557.

18. Li S, Sengupta D, Chien S (2014) Vascular tissue engineering: from in vitro to in situ. Wiley Interdiscip Rev Syst Biol Med 6(1): 61-76.

19. Bell J, Haycock J (2012) Next generation nerve guides: materials, fabrication, growth factors, and cell delivery. Tissue Eng B Rev 18(2): 116-128.

20. Bueno EM, Glowacki J (2009) Cell-free and cell-based approaches for bone regeneration. Nat Rev Rheumatol 5(12): 685-697.

21. Williams DF (2014) The biomaterials conundrum in tissue engineering. Tissue Eng Part A 20(7-8): 1129-1131.

22. Langer R, Vacanti JP (1993) Tissue engineering. Science 260(5110): 920-926.

23. Liao CJ, Chen CF, Chen JH, Chiang SF, Lin YJ, et al. (2002) Fabrication of porous biodegradable polymer scaffolds using a solvent merging/ particulate leaching method. J Biomed Mater Res 59(4): 676-681.

24. Murphy WL, Dennis RG, Kileny JL, Mooney DJ (2002) Salt fusion: an approach to improve pore interconnectivity within tissue engineering scaffolds. Tissue Eng 8(1): 43-52.

25. Hou QP, Grijpma DW, Feijen J (2003) Porous polymeric structures for tissue engineering prepared by a coagulation, compression moulding and salt leaching technique. Biomaterials 24(11): 1937-1947.

26. Harris LD, Kim BS, Mooney DJ (1998) Open pore biodegradable matrices formed with gas foaming. J Biomed Mater Res 42(3): 396-402.

27. Nam YS, Yoon JJ, Park TG (2000) A novel fabrication method of macroporous biodegradable polymer scaffolds using gas foaming salt as a porogen additive. J Biomed Mater Res 53(1): 1-7. 


\section{Current Trends in Fashion Technology \& Textile Engineering}

28. Salerno A, Oliviero M, Di Maio E, Iannace S, Netti PA (2009) Design of porous polymeric scaffolds by gas foaming of heterogeneous blends. J Mater Sci Mater Med 20(10): 2043-2051.

29. Nam YS, Park TG (1999) Biodegradable polymeric microcellular foams by modified thermally induced phase separation method. Biomaterials 20(19): 1783-1790.

30. Akbarzadeh R, Yousefi A (2014) Effects of processing parameters in thermally induced phase separation technique on porous architecture of scaffolds for bone tissue engineering. J Biomed Mater Res B Appl Biomater 102(6): 1304-1315.

31. Ho MH, Kuo PY, Hsieh HJ, Hsien TY, Hou LT, et al. (2004) Preparation of porous scaffolds by using freeze-extraction and freeze-gelation methods. Biomaterials 25(1): 129-138.

32. Qian L, Zhang H (2011) Controlled freezing and freeze drying: a versatile route for porous and micro-/nano-structured materials. J Chem Technol Biotechnol 86(2): 172-184.

33. Whang K, Thomas $\mathrm{CH}$, Healy KE, Nuber G (1995) A novel method to fabricate bioabsorbable scaffolds. Polymer 36(4): 837-842.

34. Giannitelli SM, Accoto D, Trombetta M, Rainer A (2014) Current trends in the design of scaffolds for computer-aided tissue engineering. ActaBiomater 10(2): 580-594.

35. Dalton PD, Vaquette C, Farrugia BL, Dargaville TR, Brown TD, et al (2013) Electrospinning and additive manufacturing: converging technologies. Biomater Sci 1(2): 171-185.

36. Hollister SJ (2005) Porous scaffold design for tissue engineering. Nat Mater 4(7): 518-524.

37. Braghirolli DI, Steffens D, Pranke P (2014) Electrospinning for regenerative medicine: a review of the main topics. Drug Discov Today 19(6): 743-753.

38. Tamayol A, Akbari M, Annabi N, Paul A, Khademhosseini A, et al. (2013) Fiber-based tissue engineering: progress, challenges, and opportunities. Biotechnol Adv 31(5): 669-687.

39. Wang X, Han C, Hu X, Sun H, You C, Gao C, et al. (2011) Applications of knitted mesh fabrication techniques to scaffolds for tissue engineering and regenerative medicine. J Mech Behav Biomed Mater 4(7): 922-932.

40. Gloy Y, Loehrer M, Lang B, Rongen L, Gries T, et al. (2013) Tubular woven narrow fabrics for replacement of cruciate ligaments. Ann Biomed Eng 41(9): 1950-196.

41. Moutos FT, Freed LE, Guilak F (2007) A biomimetic three-dimensional woven composite scaffold for functional tissue engineering of cartilage. Nat Mater 6(2): 162-167.

42. Ahn H, Kim KJ, Park SY, Huh JE, Kim HJ, et al. (2014) 3D braid scaffolds for regeneration of articular cartilage. J Mech Behav Biomed Mater 34 37-46.

43. Anitua E, Sanchez M, Orive G (2010) Potential of endogenous regenerative technology for in situ regenerative medicine. Adv Drug Deliv Rev 62(7-8): 741-752.
44. Ribba L, Parisi M, D’Accorso NB, Goyanes S (2014) Electrospun nanofibrous mats: from vascular repair to osteo integration. J Biomed Nanotechnol 10(12): 3508-3535.

45. Ingavle GC, Leach JK (2014) Advancements in electrospinning of polymeric nanofibrous scaffolds for tissue engineering. Tissue Eng Part B Rev 20(4): 277-293.

46. Yokoya S, Mochizuki Y, Nagata Y, Deie M, Ochi M (2008) Tendonbone insertion repair and regeneration using polyglycolic acid sheet in the rabbit rotator cuff injury model. Am J Sports Med 36(7): 1298-12309.

47. Quigley AF, Bulluss KJ, Kyratzis ILB, Gilmore K, Mysore T, et al. (2013) Engineering a multimodal nerve conduit for repair of injured peripheral nerve. J Neural Eng 10(1): 016008.

48. Puppi D, Zhang X, Yang L, Chiellini F, Sun X, et al. (2014) Nano/ microfibrous polymeric constructs loaded with bioactive agents and designed for tissue engineering applications: a review. J Biomed Mater Res B Appl Biomater 102(7):1562-1579.

49. Toskas G, Bruenler R, Hund H, Hund R, Hild M, et al. (2013) Pure chitosan microfibres for biomedical applications. Autex Res. J 13: 134140 .

50. Younesi M, Islam A, Kishore V, Anderson JM, Akkus O (2014) Tenogenic induction of human MSCs by anisotropically aligned collagen biotextiles. Adv Funct Mater 24(36): 5762-5770.

51. Li Z, Ji S, Wang Y, Shen X, Liang H (2013) Silk fibroin-based scaffolds for tissue engineering. Front Mater Sci 7(3): 237-247.

52. Schacht K, Scheibel T (2014) Processing of recombinant spider silk proteins into tailor-made materials for biomaterials applications. Curr Opin Biotechnol 29: 62-69.

53.Williams DF (2014) The biomaterials conundrum in tissue engineering. Tissue Eng Part A 20(7-8): 1129-1131.

54. Hild M, Bruenler R, Jaeger M, Laourine E, Scheid L, et al. (2014) Net Shape Nonwoven: a novel technique for porous three-dimensional nonwoven hybrid scaffolds. Text Res J 84(10): 1084-1094.

55. Inada Y, Hosoi H, Yamashita A, Morimoto S, Tatsumi H, et al. (2007) Regeneration of peripheral motor nerve gaps with a polyglycolic acid-collagen tube: technical case report. Neurosurgery 61(5): E1107.

56. Aberg M, Ljungberg C, Edin E, Millqvist H, Nordh E, et al. (2009) Clinical evaluation of a resorbable wrap-around implant as an alternative to nerve repair: a prospective, assessor-blinded, randomised clinical study of sensory, motor and functional recovery after peripheral nerve repair. J Plast Reconstr Aesthet Surg 62(11): 1503-1509.

57. Honkanen PB, Tiihonen R, Skytta ET, Ikavalko M, Lehto MUK, et al. (2010) Bioreconstructive poly-L/D-lactide implant compared with swanson prosthesis in metacarpophalangeal joint arthroplasty in rheumatoid patients: a randomized clinical trial. J Hand Surg Eur 35(9): 746-753.

58. Cooper JA, Sahota JS, Gorum WJ II, Carter J, Doty SB, et al. (2007) Biomimetic tissue-engineered anterior cruciate ligament replacement. Proc Natl Acad Sci USA 104(9): 3049-3054. 
(C) This work is licensed under Creative Commons Attribution 4.0 Licens

DOI: 10.19080/CTFTTE.2018.04.555630

\section{Your next submission with Juniper Publishers will reach you the below assets}

- Quality Editorial service

- Swift Peer Review

- Reprints availability

- E-prints Service

- Manuscript Podcast for convenient understanding

- Global attainment for your research

- Manuscript accessibility in different formats ( Pdf, E-pub, Full Text, Audio)

- Unceasing customer service

Track the below URL for one-step submission https://juniperpublishers.com/online-submission.php 